\title{
The Application of Legal Sanctions Against Corporate Crimes from the Perspective of Law Enforcement
}

\author{
Akhmad Fauzi ${ }^{1}$, Zudan Arief Fakrulloh ${ }^{2}$ \\ \{jangkargroups@gmail.com ${ }^{1}$,cclsis@yahoo.com ${ }^{2}$ \} \\ Universitas Borobudur, Jakarta, Indonesia ${ }^{1,2}$
}

\begin{abstract}
This review looks at the Application of Legal Sanctions Against Corporate Crimes according to the viewpoint of law requirement. The presence of the organization isn't framed without an objective and in the accomplishment of corporate targets is constantly showed through deeds of human instinct. In Indonesia, the situation of the enterprise as a subject of criminal law: this is recently perceived in the Legislation overseeing criminal demonstrations outside of the criminal code. Concerning a portion of the Laws that as of now oblige the situation of the company as a subject of criminal law will be Law No. 8 of 2010 on the Prevention and Eradication of Money Laundering, Law No. 41 Year 1999 on Forestry, and Law Number 32 Year 2009 on the Management and Protection of Environment. The aim of this research is to analyze the sanctions against corporate crime from a law enforcement perspective and to analyze the form of legal certainty against corporate crime from a law enforcement perspective. The research uses a normative legal approach that puts pressure on the research of the library. In this study, what we're using is the Law Approach, the Conceptual Approach, the Legal Approach, the Case Approach, and the Historical Approach. Based on the results of the study showed that the Nature of corporate crime is basically a crime prohibited or censured by any law. Corporate crime is an act which is arranged on any laws that apply. Corporate crimes can be reviewed based on the model of the crimes committed. From the corner of the form of legal certainty, so that the efforts to overcome corporate crime not only can be done by applying the provisions of the criminal laws are there, but needs to be done comprehensive understanding and critical of various conditions that includes the phenomenon of corporate crime.
\end{abstract}

Keywords: Sanctions Law; Corporate; Law Enforcement

\section{Introduction}

\subsection{Background}

According to Moeljatno, criminal acts according to the Indonesian Criminal Code system are divided into crimes (misdrijven) and violations (overtredingen).[1] Criminal acts generally occurs because of an intent element, the element of chance perpetrators of criminal acts and elements victim of a criminal act, with the following formula: If one element does not exist, 
then nothing will happen a criminal offense. Elements of the intentions of the perpetrators of criminal acts there, but the element of chance perpetrators of criminal acts do not exist, even though the victims there, there will be no crime because the victim has security into the security and out very tight, both physical and non-physical. Similarly, although the element of chance and the victim is there, but the intentions of the perpetrators of criminal acts do not exist, then the crime will not happen, will not be also a criminal offence, when no criminal although the intent element and the element of victims there.[2]

The perpetrators of crimes in the development of the criminal law, not only done by man as a subject of law, but also done by the corporation. The plan of the Indonesian criminal law additionally takes on and perceive the company as a subject of criminal law, as there is in the BILL of the criminal code which have consolidated enterprise as a subject of criminal law. Despite the fact that it has not been or alternately isn't perceived in the PENAL code pertinent right now. Individuals and corporations as subjects of criminal law has meaning, that both can be held responsible for its own, not an alternative. The rationale of criminal responsibility individual is addressed as a result of the individual that resulted in harm to another person or another group. To the corporation is intended to 'replace" the losses incurred in the framework creates a sense of justice for the people whose rights have been sacrificed. In the development of the corporation not just as subjects of civil law, but has shifted to be the subject of criminal law. Judging from the shape of the subject and his motives.

Although it has not been or is not recognized in the PENAL code applicable at this time. Aligned individuals and corporations as subjects of criminal law has meaning, that both can be held responsible for its own, not an alternative. The rationale of criminal responsibility individual is addressed as a result of the individual that resulted in harm to another person or another group. To the corporation is intended to 'replace" the losses incurred in the framework creates a sense of justice for the people whose rights have been sacrificed. In the development of the corporation not just as subjects of civil law, but has shifted to be the subject of criminal law. Judging from the shape of the subject and his motives. Corporate crime can be categorized as white-collar crime (white collar crime) as organized crime.

Another term that appears and associated with crime, white-collar, criminal economies, and the criminal acts of the corporation is "criminal business", which by Conklin formulated that the elements of Business Crimes are as follows. 1. An act against the law which is punishable by criminal sanctions. 2. Done by a person or corporation in their lawful business or in search or business in the fields of industry or trade. 3. Aims to acquire money or wealth, avoid payment or avoid loss or loss of wealth, or obtain a business advantage or personal gain.[3]

Uncover the evil corporation is not a something that simple, because the level of complexity and complexity. White-collar crime (white collar crime) and corporate crime (corporate crime) more serious than other crimes such as burglary (burglary) and robbery (robbery). Thinking about corporate crime raises the pros and cons among the experts in the law, especially criminal law. In the criminal there is a doctrine that evolved namely the doctrine of the university of delinquere non potest (corporations may not be criminal). This thinking influenced, that the existence of the corporation in the criminal law are just a fiction of law does not have a mind, so it does not have a moral value that is required to be blamed for the criminal (the elements of the error). Whereas in a offense/crime requires the presence of the fault (mens rea) in addition to the act (actus reus) or known (actus non facit reum, nisi mens sit re).

In 1955 the maker of the law relating to Criminal Economy has already felt the need to expressly deviate from the general principle of Article 59 of the criminal code, to be able to 
load and drop the criminal to the corporation (in addition to the managers). Before 1955, of a criminal offense can only be done by people. However, this establishment has long been abandoned for some offense, such as the economic criminal act (Act No. 7, 1955), although at that time still used the term a legal entity, a company, a united people, or foundation, as well as other terms of the corporation. It is proved settings regarding the involvement of a corporation in a criminal actually is not new, but has long since been thought out by the compilers of the law.[4]

The perpetrators of crimes in the development of the criminal law, not only done by man as a subject of law, but also done by the corporation. The design of the Indonesian criminal law also adopts and recognize the corporation as a subject of criminal law, as there is in the BILL of the criminal code which have incorporated corporation as a subject of criminal law. Although it has not been or is not recognized in the PENAL code applicable at this time. Aligned individuals and corporations as subjects of criminal law has meaning, that both can be held responsible for its own, not an alternative. The rationale of criminal responsibility individual is addressed as a result of the individual that resulted in harm to another person or another group. To the corporation is intended to 'replace" the losses incurred in the framework creates a sense of justice for the people whose rights have been sacrificed. In the development of the corporation not just as subjects of civil law, but has shifted to be the subject of criminal law. Judging from the shape of the subject and his motives.

Although it has not been or is not recognized in the PENAL code applicable at this time. Aligned individuals and corporations as subjects of criminal law has meaning, that both can be held responsible for its own, not an alternative. The rationale of criminal responsibility individual is addressed as a result of the individual that resulted in harm to another person or another group. To the corporation is intended to 'replace" the losses incurred in the framework creates a sense of justice for the people whose rights have been sacrificed. In the development of the corporation not just as subjects of civil law, but has shifted to be the subject of criminal law. Judging from the shape of the subject and his motives. Corporate crime can be categorized as white-collar crime (white collar crime) as organized crime.

Another term that appears and associated with crime, white-collar, criminal economies, and the criminal acts of the corporation is "criminal business", which by Conklin formulated that the elements of Business Crimes are as follows. 1. An act against the law which is punishable by criminal sanctions. 2. Conducted by a person or corporation in his lawful employment or in his pursuit or business in industry or commerce. 3. Aims to acquire money or wealth, avoid payment or avoid loss or loss of wealth, or obtain a business advantage or personal gain.[5]

\subsection{Problem Formulation}

The formulation of the problem in this research is how the rule of law regarding the enforcement of corporate law? and how the pattern of punishment is the ideal against corporate crime environment.?

\subsection{The Purpose Of The Study}

The motivation behind this review is to examine law and order for law and order in regards to the authorization of the law of partnerships and to break down the examples of discipline is the ideal against corporate wrongdoing climate. 


\section{Methodology}

The technique utilized in this review the sort of lawful exploration is standardizing juridical. That is, research the law recorded as a hard copy dependent on writing. In the context of normative juridical is that the research is focused to study the application of rules or norms in positive law [6] A normative juridical approach is the approach which is based on the material of the main law by way of reviewing the theories, concepts, principles of the law as well as laws and regulations that relate to this research. Sources of law used is the primary data source and secondary data source, the Analysis used in this research is qualitative analysis.

\section{Discussion}

\subsection{The Rule of Law Regarding the Enforcement of Corporate Law}

The term "crime of the corporation" in some of the literature often referred to as the "corporate crime". This term basically does not appear by itself, but rather appeared along with the development of the times and the development of society. The beginning of the birth of criminal acts of the corporation is to depart from the opinion of Edwin Sutherland suggests the types of crimes that are known as white-collar crime. Related to white collar crime itself, Hazel Croal was quoted as saying by Yusuf Shofie give the definition is as: white-collar crime is often associated with various scandals the world of finance and business (financial and business world) and advanced fraud by senior executives (the sophisticated frauds of senior executives) that included what is popularly known as a criminal act corporations (corporate crime).[7]

In general, the phenomenon of law in Indonesia, corporation or legal entity can only be accounted for in the criminal law with parameters:[8] (1) Unlawful acts are committed by people who have a working relationship or other relationship with a legal entity / corporation; and, (2) the unlawful act is carried out in the environment / atmosphere of the legal entity / corporation as seen from the articles of association of the legal entity / corporation. Regarding corporate crime or corporate crime, Steven Box stated the type and characteristics of criminal acts committed by corporations that are basically different from criminal acts or conventional crimes in general. Steven Box stated that the scope of corporate criminal acts surrounds:[9]

1. Crimes for corporations, which are crimes or violations of the law committed by corporations in achieving certain efforts and goals in order to obtain profits.

2. Criminal enterprise, which is an organization that points exclusively to perpetrate violations. (for this situation the partnership is just as a front of a wrongdoing association).

3. Crimes against corporation, which are crimes against corporations such as theft or embezzlement of corporate property, in this case the corporation as a victim. In this article, what is discussed is only crimes for corporations, namely crimes or violations of law committed by corporations in achieving certain efforts and goals to obtain profits. With regard to victims of corporate crime, Muladi distinguishes between victims of conventional crime and victims of corporate crime as follows: "In conventional crime, the victim can be identified easily, while in corporate crimes the victim is often abstract, such as the government, other companies or consumers who are many, while individually the loss is very little.".[10] 
In addition, according to Clinard and Yeager, there are six types of victims of corporate crime, namely:[10]

1. The consumer (the security or quality of the products). When the risk of health and safety associated with the use of the product, then the consumer has been a victim of such products.

2. Consumers (economic power). Violation of credit, which gives incorrect information in advertising with the aim to influence consumers.

3. Most of the economic system has been affected by the practices of trading dishonest directly (violation of the provisions of the anti-monopoly violations against the regulations of the competition of the other) and most of the financial abuses unless related to a grocery consumers.

4. Violation of the environment (pollution of air and water), which becomes the victim i.e. the physical environment.

5. Labor becomes the victim in violation of the provisions of the wages.

6. The government become a victim, because of the presence of violations of administrative or court order, and cases of tax fraud. In addition, the criminal acts of the corporation has been incurring losses in various fields such as loss of field:

a. Losses in the field of economic or material losses. Events showed that the level of economic losses caused by the crime is enormous, especially when compared with the losses inflicted by the evil shop such as robbery, theft, fraud. For example, estimates made by Subcommitee on Antitrust and Monoplay of the US Senate Judiciary Committees chaired by Senator Philip Hart estimate the harm caused by corporate crime between 174-231 billion dollars per year. This is a number that very much when compared to the crime shops which ranges from 3-4 billion.

b. Losses in the field of health and salvation of the soul. According to Geis, each year the corporation is responsible for thousands of deaths and disabilities of the body that occur around the world. The risk of death and disability caused by the corporation can be caused by either the products produced by the corporation or in the process of production, so that became the victims of corporate crime is the wider community, in particular consumers and those who work on corporate ads.

c. Losses in the field of social and moral. The economic losses, health and soul, the loss is no less important that inflicted by the evil corporation is a loss in the field of social and moral. The impact caused by corporate crime is damaging public trust in the conduct of a business. The President's Commission on Law Enforcement and Administration of Justice once stated that corporate crime is a crime of the most important worrisome not only because of the disadvantage that very large, but due to the damage against size-the size of the moral conduct of the business of the American people. Business crime (corporate) undermines public confidence in the system business, for the crimes thus integrated into the structure of the legitimate business (the structure of legitimate business).

In its development that occurs is an emerging doctrine or theory of replacement named theory of identification (identification theory) or (alter ego theory), which states that:[11]

1. A voluntary approach to change both behavior and corporate structure

2. A strong intervention through state politics to change by force corporate structure (a corporate organizational regime) accompanied by a criminal law sanction, civil and/or administration to a deterrent effect

3. The actions of consumers (consumer action and pleasure) boycott on products corporation. 
With the adoption of a regime of corporate criminal liability, the objections against the possibility of the occurrence of double sanctioning or ne bis in idem because of the possibility of convict individuals and corporate at the same time can be ruled out. Decisive action and severe criminal against the corporation above can only be done with consideration for the protection against the society, the history of the corporation whose dangerous mismanagement management, a really irresponsible and so on. Such sanctions could include a ban on performing certain activities, can also include a ban on performing certain activities, a ban on bidding particular, the ban on producing certain goods, a ban on the contract and put up advertising. Sanctions include placement under the supervision or oversight under probation and community service order can also be imposed.

Basic punishment can be meted out against corporate crime is just criminal fines (fine), but if the sanctions imposed measures such as closing the entire corporation, is basically a corporate death penalty, while the sanctions in the form of restrictions on the activities of the corporation.[11] Thus, the doctrine of criminal liability charged to the corporation in the Law No. 18/2012 using the doctrine of criminal liability is strict (strict liability) that when a corporation violates or does not meet the obligation/condition/situation specific as set out in the legislation.[12] However, Law No. 18/2012 not set if the corporation's repeat of criminal acts, and the reason the eraser the criminal for the corporation. The absence of such an arrangement is a form of weakness in terms of the formulation of corporate criminal liability if found committing a criminal act of hoarding.

The settings of the corporation as a subject of criminal offences contained in the various laws and regulations specifically on the outside of the criminal code of the scope is arranged in such a broad (broader than the notions of corporate in civil law), namely as stipulated in Law No. 7 Drt 1955 about the Criminal Economy; Law No. 8/1995 about the Capital Market; Law No. 5/1997 on Psychotropic substances; the Law No. 6/1984 about the Post; Law No. $5 / 1984$ about the Industry; and so forth. Based on the provisions in various laws such, Barda Nawawi Arief conclude that:[13]

1. The determination of the corporation as the subject of the crime only to specific criminal acts, which are arranged in a special law;

2. was not initially used the term "corporation", but used the term variety (not uniform) and not consistent;

3. The term "corporation" started to look at the year 1997 in the Legislation of Psychotropic influenced by the term in the Concept of the criminal code or the Draft of the criminal code of 1993.

Thus, the corporation can only be accounted for against the actions of the individual who acts on behalf of the corporation and the person has a high position or plays a key function in the structure of the decision-making corporation.[8]

\subsection{Patterns of Punishment is the Ideal Against Corporate Crime Environment}

Setting the accountability of the corporation in criminal law in Indonesia is regulated in RKUHP 2012 issued by the Ministry of Law And human RIGHTS. These settings are contained in Book I of the PENAL code (General Provisions). As has happened in the Netherlands in 1976. In Article 47 to Article 53 of the RKUHP is successively formulated that:[11]

a. The enterprise is the subject of a criminal offense, if the offense carried out by individuals who have been practical in the authoritative construction of the partnership to represent and for the organization or the purpose of corporate interests, in view of the relationship of 
the work relationship or under some other relationship, inside the extent of business of the company, either alone or together;

b. In the event that a criminal demonstration is finished by enterprises, criminal responsibility is forced against the partnership and additionally its administration;

c. The company can be represented in the criminal procedures against a demonstration done for or potentially for the organization, if the demonstration is inside the extent of its business as indicated in the articles of affiliation or different arrangements that apply to the enterprise concerned;

d. Criminal liability of cooperative management limited throughout the board have been functional in the organizational structure of the corporation;

e. In thinking about a criminal indictment, it should be viewed as regardless of whether the law has been the insurance that is more helpful than dropping criminal procedures against a company;

f. The considerations referred to should be stated in the verdict of the judge;

g. Justification for excusing or support that can be requested by the creators from the represent as well as in the interest of the partnership, might be recorded by the enterprise of the multitude of reasons that keeps going related with deeds are charged in the organization.

From the article 47-53 RKUHP it can be concluded that the corporation is the subject of a criminal offense may be subject to liability in a criminal corporation. Reason for forgiving or justification that can be asked by the makers of the act for and/or on behalf of the corporation, may be filed by the corporation of all of these reasons directly related to the act are prosecuted to the corporation. Whereas according to article 1653 of the Civil CODE of the Legal Entity can be divided into: (a) a legal Entity established by the government; provinces; the government banks; (b) a legal Entity which is recognized by the government; of the company; the church; (c) a legal Entity established for a specific purpose; PT, cooperative, foundation.

Condition $d$ is that there must be separation of wealth, has a specific purpose, have their own interests, and the presence of organizations that regularly. The terms of her is a must qualify that had to do with a request to obtain the status as a legal entity. In RKUHP which belongs to the corporation includes not only the legal entities, but also covers the firm, CV, and the fellowship is a business entity that is based on civil law, not a legal entity.[13]

In addition to the rules in the RKUHP issue did the Supreme Court Regulation No. 13 of 2016 on procedures for Handling Criminal Cases by the Corporation. In Perma, the judge declared the corporation to make a mistake that can be punished, if: (1) the corporation may derive profit or benefit from these criminal acts or criminal acts is done for the benefit of the corporation; (2) the corporation allow the occurrence of the criminal offense; (3) the corporation does not undertake measures necessary for the prevention, prevent a greater impact and ensure compliance with the provisions of applicable laws in order to avoid the occurrence of the criminal offense.

In Perma, the subject of the law is the corporation and the board of the corporation, in Perma is mentioned also several levels of punishment, namely: (1) a fine to the corporation; (2) if the corporation does not pay the fine, then the assets can be seized and seized; (3) a fine to the board of the corporation; (4) if the management of the corporation does not pay the fine then replaced with imprisonment proportionately. In Perma No. 13 of 2016 is also set forth the entire execution process executed according to the criminal procedure code. As for the deprivation of evidence, according to the criminal procedure code, then the deprivation of evidence managed Storage House State Confiscated Objects (Rupbasan). 


\section{Conclusion}

The enforcement of the Law of corporations in criminal law in Indonesia is regulated in RKUHP 2012 issued by the Ministry of Law and human RIGHTS, found in Book I of the PENAL code (General Provisions). Article 1653 of the Civil CODE distinguishes a legal entity to be: (a) a legal Entity established by the government; provinces; the government banks; (b) a legal Entity which is recognized by the government; the company; the church; (c) a legal Entity established for a specific purpose; PT, cooperative, foundation. Terms of materiel is to be no separation of wealth, has a specific purpose, have their own interests, and the presence of organizations that regularly. The terms of her is a must qualify that had to do with a request to obtain the status as a legal entity. In RKUHP which belongs to the corporation includes not only the legal entities, but also covers the firm, $\mathrm{CV}$, and communion, that is a business entity that is based on civil law, not a legal entity. While for the handling of criminal acts of corporations poured in Perma No. 13 of 2016. The government is expected to provide a setting guideline which is definitely against the law in addressing corporate crime. It also provides or creates the formulation of policies that are appropriate in the handling of corporate crime in the form of criminal law.

\section{References}

[1] Moeljatno. Principles of Criminal Law. Rineka Cipta, Jakarta, p. 78 (2008)

[2] Adussalam. Victimology. PTIK, Jakarta p. 259 (2010)

[3] Hutauruk, Rufinus Hotmaulana. Penganggulangan Kejahatan Korporasi Melalui Pendekatan Restoratif Suatu Terobosan Hukum. Sinar Grafika, Jakarta, p. 3-4 (2013)

[4] Yunara, Edi. Korupsi dan Pertanggungjawaban Pidana Korporasi. p. 55 (2005)

[5] Sugianto, Fajar. Economic Approach of Law. Jakarta: Prenada Media, $2^{\text {nd }}$ Edition, p. 98 (2015)

[6] Ali, Zainudim. Metode Penelitian Hukum. Sinar Grafika, Jakarta, p. 31 (2009)

[7] Shofie, Yusuf. Pelaku Usaha, Konsumen dan Tindak Pidana Korporasi, Ghalia Indonesia, Jakarta. (2002)

[8] Nyoman Serikat Putra Jaya, 2010, Globalisasi HAM dan Penegakan Hukum. Paper: submitted at the student matriculation of the Undip Law Magister Program in 2010, on 18 September.

[9] Muladi, and Dwidja Priyatno. Pertanggungjawaban Korporasi Dalam Hukum Pidana, STHB, Bandung. (1991)

[10] Amrullah, Arief. Corporate Crime (The Hunt for Mega Profits and the Attack on Democracy), Banyumedia Publishing, Malang. (2006)

[11] Muladi dan Diah Sulistyani. Pertanggungjawaban Pidana Korporasi, PT. Alumni, Bandung. (2015)

[12] Arief, Barda Nawawi. Bunga Rampai Kebijakan Hukum Pidana. Penerbit Kencana Prenada, Jakarta. (2014)

[13] Barda Nawawi Arief, Kapita Selekta Hukum Pidana, Citra Aditya Bakti, Bandung, 2003, hlm. 226..

[14] Bryan A. Garner (Ed.), 2003, Black's Law Dictionary, Second Pocket Edition.

[15] Danang Sutoyo, Wika Harisa Putri, 2016, Hukum Bisnis, Pustaka Yustisia, Yogyakarta.

[16] Kenneth S. Ferber, 2002, Corporation Law, Prentice Hall. 
[17] Peter Gillies (Penyunting Barda Nawawi Arief), 2003, Criminal Law, tanpa penerbit, tanpa kota.

[18] Satjipto Rahardjo, 2000, Ilmu Hukum, Citra Aditya Bakti, Bandung. 